\title{
A szuperkondenzátorok és katonai alkalmazhatóságuk
}

\section{A HAGYOMÁNYOS KONDENZÁTOROK ÉS JELLEMZŐIK ÖSSZEFOGLALÁSA}

A hagyományos kondenzátorok már régről ismert elektrotechnikai alkatelemek. Az első ilyen szerkezet tulajdonképpen a közismert leideni-palack volt. Ezt 1745-ben egymástól függetlenül a német Ewald Georg von Kleist és a leideni egyetemen dolgozó holland fizikus, Pieter van Musschenbroek is megépítette [1]. Ez volt az első olyan eszköz, amely segítségével tárolni tudták a statikus úton előálított elektromosságot. Így ez a palack tekinthető minden villamos energiatároló ősének. A modern kondenzátorok őse a papírkondenzátor ${ }^{1}$, már az 1800-as évek végén megjelent. $\mathrm{Az}$ elektrotechnika, majd később az elektronika és mikroelektronika forradalmával a XX. századra a kondenzátorok már a mindennapok részévé váltak. Bár ennek nem nagyon vagyunk tudatában, de egy átlagos háztartásban százszámra megtalálhatóak ezek az eszközök akár diszkrét áramköri elemként, akár az áramköri lapokra integrálva.

A kondenzátorok felépítése igen egyszerű, két elektromos vezetőből, úgynevezett fegyverzetből és a köztük lévő dielektrikumból, azaz szigetelő-rétegből állnak [2, 141. o.]. Amennyiben a fegyverzetre egyenfeszültséget kapcsolunk², azok feltöltődnek, a fegyverzeteken összegyűlő elektromos töltések nagysága pedig arányos a feszültséggel. Az ezt leíró (egyenfeszültségű) egyenlet: $Q=C U$ [2, 140. o.], amelyből látható, hogy a kapacitás ${ }^{3}$ a legfőbb jellemzője minden ilyen eszköznek, egyfajta arányossági tényező a feszültség és a töltésmennyiség között. A kapacitás annál nagyobb, minél nagyobb töltésmennyiséget képes felvenni, minél kisebb feszültség mellett. Ha ezt a geometriai kialakítás szempontjából vizsgáljuk, akkor a kapacitásérték annál nagyobb, minél nagyobb a fegyverzetek felülete, illetve minél közelebb helyezkednek el egymáshoz úgy, hogy még nem jön létre átütés, azaz minél jobb a szigetelőréteg dielektromos állandója (azaz szigetelő-képessége). A kapacitás nagysága levezethető a $Q=C U$ egyenletből: $C=\frac{Q}{U}$.

A gyakorlati elektronikában alkalmazott hagyományos, ún. „száraz” kondenzátorok kapacitása csupán pF és nF $\left(10^{-12}\right.$ és $10^{-9}$ farad) nagyságrendű. Bár már 1928-ban szabadalmaztatták [3], igazából csak az 1970-es években terjedtek el az elektrolit kondenzátorok, ahol az egyik fegyverzet egy vezetőképes folyadék, azaz elektrolit. Az elektrolit miatt ezek az eszközök már polarizáltak, vagyis csak egyenfeszültségü áramkörökben alkalmazhatók, ugyanakkor a kapacitásuk nagyságrendileg meghaladja a szárazkondenzátorokét, és már a $\mu \mathrm{F}\left(10^{-6}\right.$ farad) tartományba esik. A kondenzátorok mindenkori energiája: $W=\frac{1}{2} C U^{2}$ [2, 143. o.], azaz nagy energiához nagy feszültség és kapacitás tartozik. Ebből sejthető, hogy az elektronikai célokra gyártott legnagyobb méretű és kapacitású eszközök által tárolt energia is csak néhány Joule, azaz kimondottan energetikai célokra (nagy mennyiségü munka végzéséhez szükséges energia biztosítására) nem alkalmasak.

A valós kondenzátorok teljes modellje természetesen komplexebb, de jelen cikk keretei között csak az egyenáramú energiaviszonyokat vizsgáljuk, egy viszonylag egyszerű modell segítségével:

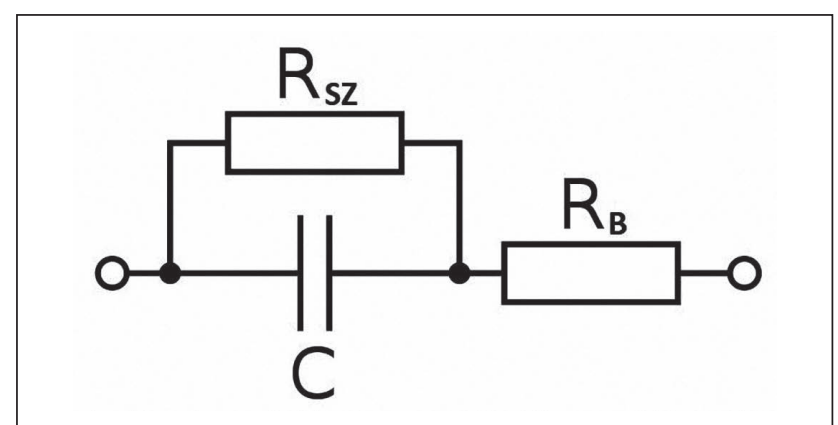

1. ábra. A kondenzátor egyszerüsített egyenáramú energetikai modellje

A modellben az $R_{\mathrm{sz}}$ a kondenzátor dielektrikumának tökéletlenségét szimbolizálja. Amennyiben egy feltöltött kondenzátort magára hagyunk, akkor a dielektrikumon elkezdenek átszivárogni a töltött részecskék. Az így létrejövő $I_{\text {sz }}$ szivárgási áram pedig lassan kisüti, lemeríti azt. Az $R_{\mathrm{B}}$ pedig azt az energiaveszteséget szimbolizálja, ami a kondenzátor szándékolt kisütésekor, illetve feltöltésekor jelentkező hőmérséklet-növekedés formájában tapasztalható.

ABSTRACT: There are several types of electrical energy equipment that are hardly known in non-professional circles. One of them is a supercapacitor, it is a very interesting tool thanks to its capabilities. By its parameters it can be considered to unique, so it is indispensable to use some very special equipment. With the rise of electricity, there will be more and more military equipment, where there is currently no alternative to its use. It is therefore worth knowing a little better more about that.

\section{KEY WORDS: supercapacitor, battery, electrical energy storage}

* Mk. alezredes, MH Modernizációs Intézet, NKE Hadtudományi és Honvédtisztképző Kar, Katonai Műszaki Doktori Iskola, vegvari.zsolt@hm.gov.hu. ORCID: 0000-0003-2543-6049 


\section{A SZUPERKONDENZÁTOROK ${ }^{4}$ TÖRTÉNETE ÉS FIZIKÁJA}

Először 1950-es években a General Electric kísérletezett porózus szénelektródákkal, a hagyományos kondenzátorok, akkumulátorok és üzemanyagcellák fejlesztése érdekében, ugyanis a szénelektródák tördelt felszíne rendkívül nagy felületet képezett, ami igen előnyös volt ezekben az eszközökben. Egy bizonyos kettős rétegű konstellációban rendkívüli módon megnövekedett kapacitást észleltek. 1957-ben még szabadalom is született belőle, de igazi jelentőségét nem ismerték fel, és nem is kísérleteztek tovább [4]. 1966-ban a Standard Oil of Ohio munkatársai folytatták a munkát, és bár ők is üzemanyagcellákat kívántak fejleszteni, már észrevették a technológiában rejlő energiatároló potenciált [4]. Végül az első laboratóriumi eszközök az 1970-es években jelentek meg, de a gyártástechnológia csak az ezredfordulóra érte el azt a szintet, hogy kereskedelmi mennyiségben is elérhetővé váltak.

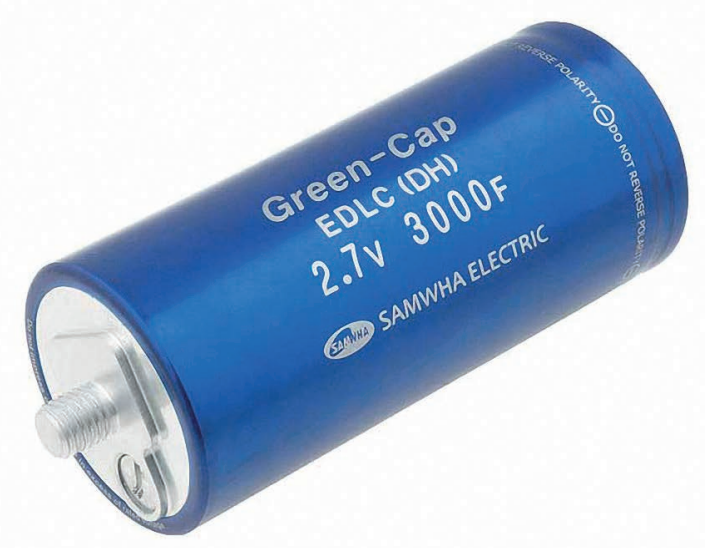

2. ábra. Egy kereskedelemben kapható szuperkondenzátor (lerablog.org)

A ma kereskedelmi forgalomban beszerezhető szuperkondenzátorok mintegy $80-90 \%$-a ún. kettős rétegű villamos kondenzátor, azaz EDLC ${ }^{5}$. Az elektródákra felvitt aktív szénréteg és az elektrolit viszonylag kompakt méretek

3. ábra. Az EDLC felépítése (Forrás: RS Components Magyarország)

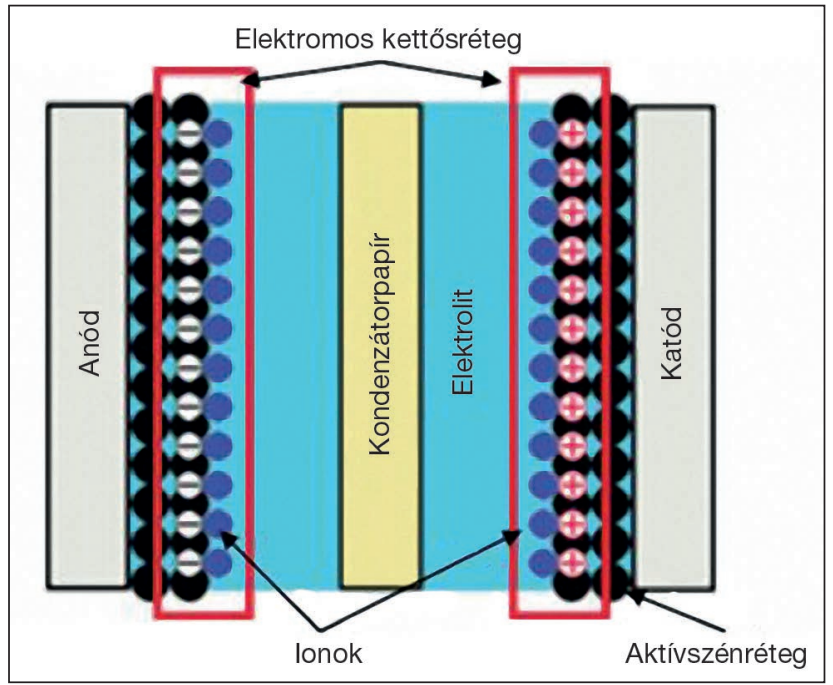

mellett nyújt a hagyományos kondenzátoroknál jóval nagyobb teljesítményt [5, 14. o.]. Fontos megjegyezni, hogy bár az EDLC-ben ez vegyi anyagok segítségével valósul meg, de a töltések tárolása fizikai. Vagyis a fegyverzeteken ténylegesen töltések helyezkednek el, és az akkumulátorokkal ellentétben, itt nincsenek vegyi átalakulások. Ezt azért kell kiemelni, mert a szuperkondenzátorok egy ritkább megvalósítási módjánál a beszédes nevű ún. pszeudo-kondenzátoroknál (pseudocapacitor) ez már nem ennyire egyértelmű. Ebben az esetben már a szénréteg felszínén létrejövő redoxidációs folyamatok is segítik a töltések megkötését [5, 15. o.].

Egyes szakértők úgy látják, hogy a közeljövő fejlesztéseivel lehetséges a szuperkondenzátorok kedvező tulajdonságainak megtartása mellett az akkumulátorokra jellemző alacsony önkisülés, illetve nagy energiasűrüség elérése is [6]. A továbbiakban csak a már jelenleg is elérhető szuperkondenzátorok által nyújtott lehetőségeket vizsgáljuk.

\section{A SZUPERKONDENZÁTOROK ÉS AZ AKKUMULÁTOROK ÖSSZEHASONLIITÁSA}

Annak érdekében, hogy a szuperkapacitásokat el tudjuk helyezni a villamos energiatárolási módok között, össze kell hasonlítanunk a ma leggyakoribb technológiával, az akkumulátorokkal. Ahogy azt korábban említettük, az akkumulátoroknál ${ }^{6}$ a feltöltés és a kisütés során vegyi reakciók zajlanak le. Ezek a folyamatok viszont sosem 100\%osak, azaz az elektródák „kopnak”, az akkumulátor „öregszik”, és így minden töltés-kisütés ciklus során veszít a kapacitásából $[7,87$. o.] Egy akkumulátort akkor tekintünk „elöregedettnek", ha a kapacitása a névleges érték $80 \%$-a alá esett. Ez a számtalan akkumulátor-technológia esetében igen eltérő, de általánosságban nagyságrendileg $10^{3}$ ciklus után következik be. Eközben a csak fizikai folyamatokkal operáló kondenzátorok öregedése minimális, élettartamuk legkevesebb $10^{6}$ ciklus. A fizikai folyamatokkal ellentétben a vegyiek erősen függnek a környezeti hőmérséklettől is. Ismert tény, hogy az akkumulátorok paraméterei a hőmérséklet csökkenésével drasztikus módon romlanak, addig a kondenzátorok erre lényegesen kevésbé érzékenyek, egyes típusok hőmérséklet/kapacitás görbéje lényegében egy vízszintest közelítő egyenes.

Az említett, nem túl előnyös tulajdonságaik ellenére a villamosenergia-tároló eszközök piacát mégis az akkumulátorok uralják. Ennek két fő oka van. Az egyik, hogy az akkumulátorok energiasűrűsége, vagyis az egységnyi tömegben vagy térfogatban tárolható energia, jóval meghaladja a szuperkondenzátorokét. A másik ok az önkisülés. Ennek magyarázata az 1. ábrán látható modellről is leolvasható, amely az elektrokémiai tárolóeszközökre, így az akkumulátorokra is alkalmazható. A szivárgási áram $\left(I_{\mathrm{sz}}\right)$ nagysága, mind az akkumulátorok, mind a szuperkondenzátorok esetében egy feszültség- és hőmérsékletfüggő görbe mentén alakul, de míg az akkumulátorok esetében hónapok kérdése, hogy a töltöttség $80 \%$ alá essen, addig ez a szuperkondenzátorok esetében csupán órákban mérhető [8, 67. o.].

Amiben a szuperkondenzátorok nagyon jól teljesítenek, az a teljesítménysürüség, vagyis, hogy egy adott pillanatban mekkora teljesítményt képesek leadni. Ennek megértéséhez ismét az 1. ábrán bemutatott modellt hívjuk segítségül. Töltéskor és kisütéskor egy úgynevezett belső ellenállása van az eszköznek (az ábrán $R_{\mathrm{B}}$ ), bár talán kifejezőbb az angolszász ekvivalens soros ellenállás $\left(E_{S R}{ }^{7}\right)$ megnevezés. Ezt az ellenállást kell a töltő- vagy kisütőáramnak le- 
1. táblázat. Hődisszipáció különböző kisütő áramok esetében akkumulátornál és EDLC-nél*

\begin{tabular}{|l|r|l|c|c|c|c|}
\hline & $\boldsymbol{R}_{\mathbf{B}}$ & Kisütő áram & $0,1 \mathrm{~A}$ & $1 \mathrm{~A}$ & $10 \mathrm{~A}$ & $100 \mathrm{~A}$ \\
\hline Akkumulátor & $100 \mathrm{~m} \Omega$ & \multirow{3}{*}{ hödisszipáció } & $1 \mathrm{~mW}$ & $100 \mathrm{~mW}$ & $10 \mathrm{~W}$ & $1 \mathrm{~kW}$ \\
\cline { 1 - 5 } EDLC & $1 \mathrm{~m} \Omega$ & & $10 \mu \mathrm{W}$ & $1 \mathrm{~mW}$ & $100 \mathrm{~mW}$ & $10 \mathrm{~W}$ \\
\hline
\end{tabular}

*A cikkben közölt táblázatokat a szerző szerkesztette

2. táblázat. A beső ellenállásra eső feszültség különböző kisütő áramok esetében akkumulátornál és EDLC-nél

\begin{tabular}{|l|c|l|c|c|c|c|}
\hline & $\boldsymbol{R}_{\mathbf{B}}$ & Kisütő áram & $0,1 \mathrm{~A}$ & $1 \mathrm{~A}$ & $10 \mathrm{~A}$ & $100 \mathrm{~A}$ \\
\hline Akkumulátor & $100 \mathrm{~m} \Omega$ & \multirow{2}{*}{$\begin{array}{l}\text { belső ellenállásra } \\
\text { eső feszültség }\end{array}$} & $10 \mathrm{mV}$ & $100 \mathrm{mV}$ & $1 \mathrm{~V}$ & - \\
\cline { 1 - 2 } & $1 \mathrm{~m} \Omega$ & & $100 \mathrm{\mu V}$ & $1 \mathrm{mV}$ & $10 \mathrm{mV}$ & $100 \mathrm{mV}$ \\
\hline
\end{tabular}

küzdenie. Ez az érték az akkumulátoroknál jellemzően $100 \mathrm{~m} \Omega$ körüli érték, míg a szuperkondenzátoroknál $100 \mu \Omega$ - $1 \mathrm{~m} \Omega$ között alakul (most csak számoljunk a kedvezőtlenebb $1 \mathrm{~m} \Omega$-al). Tegyük fel, hogy az eszközeink (egy akkumulátor és egy szuperkondenzátor) feltöltöttsége azonos (legyen ez most 2 V) és 0,1 A-rel, majd 1, 10 és 100 A-rel sütjük ki őket.

Az Ohm-törvényt alkalmazva kiszámolhatjuk a belső ellenálláson eső feszültséget: $U=I R$, és az ellenálláson disszipáló hőteljesítmény: $P=I U$. Ha ez utóbbiba behelyettesítjük az $U=I R$ összefüggést, akkor ezt kapjuk: $P=I^{2} R$. Ha egy táblázatba beírjuk a létrejövő hőteljesítményt, akkor az alábbiakat látjuk:

Még érdekesebb, ha megnézzük, hogy az eszköz 2 V-os névleges feszültségéből mennyi esik a belső ellenállásra és mennyi a fogyasztóra.

Látható, hogy amennyiben nagyobb teljesítményt akarunk kivenni az adott eszközből, az akkumulátor drasztikusan melegedni kezd, és egyre kevesebb feszültség jut a fogyasztóra. Ebben az esetben a 2 V-os cellából 100 A már elméletileg sem nyerhető ki (bár ez a fajta alkalmazás egyébként sem életszerű), miközben a szuperkondenzátor tolerálható hőveszteség mellett még mindig 1,9 V-ot juttatna a fogyasztóra. A teljes igazsághoz azonban az is hozzátartozik, hogy az akkumulátor $1 \mathrm{~A}$ terhelés mellett gyakorlatilag majdnem a teljes kisülésig csaknem konstans tartja az 1,9 V-ot, addig a szuperkondenzátor feszültsége folyamatosan csökken.

Mi a helyzet, akkor, amikor az eszközeinket fel kívánjuk tölteni? Minél gyorsabban akarunk egy eszközt feltölteni, annál nagyobb töltőáramot használunk. Ám míg az akkumulátornál a nagy belső ellenállás miatt a névlegesnél jóval nagyobb feszültséget kell rákapcsolni, addig a szuperkondenzátor gyakorlatilag a névleges feszültséggel tölthető. Az akkumulátor töltőáram- és feszültség-emelésének gátat szab, hogy a disszipáció nyomán létrejövő magas hőmérséklet károsítja az eszközt. Ennek következtében az akkumulátorok töltése elég időigényes folyamat.

A szuperkondenzátor tölthetőségét a disszipáció alig korlátozza, a csekély belső ellenállás miatt csaknem lineáris töltési görbével számolhatunk, és az alábbi képlettel: $I=C \cdot \frac{d U}{d t}[8 ., 284$. o]. Feltételezve, hogy a szuperkondenzátorunk 100 farados és 10 A-rel töltjük, a feszültsége másodperenként $100 \mathrm{mV}$-ot emelkedik, vagyis 20 másodperc alatt feltölthető. 100 A-es töltőáram mellett a töltési idő mindössze 2 másodperc.

\section{A SZUPERKONDENZÁTOROK KATONAI ALKALMAZÁSA}

A korábban leírtakból következik, hogy az akkumulátorokat ott érdemes alkalmazni, ahol tartósan nincs lehetőség a töltésre, és mindemellett fontos, hogy kisebb tömeg és térfogat mellett tudjuk tárolni az energiát. Katonai alkalmazásokat tekintve ilyen a rádiókészülék, a lámpa, illetve általában a legtöbb ma használt villamos működtetésű eszköz.

A szuperkondenzátorokat olyan eszközökben célszerü alkalmazni, ahol a töltés többé-kevésbé folyamatosan biztosítható, de időnként viszonylag nagyobb mennyiségü energiát szeretnénk nagyon rövid idő alatt, impulzusszerüen kinyerni. Mára a legkorszerübb (olykor kísérleti) rendszereknél már léteznek ilyen alkalmazási területek, így bár ritkán esik erről szó, de a szuperkondenzátorokat már a haditechnikában is alkalmazzák. Lássuk, melyek ezek a rendszerek!

\section{LÉZERFEGYVEREK}

A lézerfegyverek már nem tartoznak a tudományos fantasztikum világába. Az Egyesült Államok, Oroszország és vélhetően Kína is rendelkezik olyan rendszerekkel, ahol el-

3. táblázat. A legáltalánosabb akkumulátor- és EDLC technológiák összehasonlítása

\begin{tabular}{|c|c|c|c|c|c|c|c|}
\hline & Eszköz & $\begin{array}{l}\text { Térfogatarányos } \\
\text { energiasűrúség }\end{array}$ & $\begin{array}{l}\text { Tömegarányos } \\
\text { energiasúrúség }\end{array}$ & $\begin{array}{l}\text { Teljesítmény- } \\
\text { súrüség }\end{array}$ & $\begin{array}{l}\text { Hőmérséklet- } \\
\text { függőség }\end{array}$ & Élettartam & Önkisülés \\
\hline \multirow{4}{*}{ 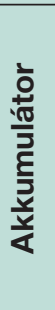 } & Ólomsavas & $100-150 \mathrm{~kJ} / \mathrm{l}$ & $90-100 \mathrm{~kJ} / \mathrm{kg}$ & 150-200 W/kg & nagy & 500 ciklus & $\begin{array}{c}\text { havonta } \\
4-6 \%\end{array}$ \\
\hline & $\mathrm{NiCd}, \mathrm{NiMH}$ & $500-1000 \mathrm{~kJ} / \mathrm{l}$ & $30-500 \mathrm{~kJ} / \mathrm{kg}$ & $200-1000 \mathrm{~W} / \mathrm{kg}$ & rendkívül nagy & $\begin{array}{c}1-2000 \\
\text { ciklus }\end{array}$ & $\begin{array}{l}\text { havonta } \\
20-30 \%\end{array}$ \\
\hline & Li-ion & $2000-2500 \mathrm{~kJ} / \mathrm{l}$ & $800-1000 \mathrm{~kJ} / \mathrm{kg}$ & $300-350 \mathrm{~W} / \mathrm{kg}$ & rendkívül nagy & $\begin{array}{c}500-1500 \\
\text { ciklus }\end{array}$ & $\begin{array}{c}\text { havonta } \\
2-3 \%\end{array}$ \\
\hline & $\mathrm{LiFePO}_{4}$ & $6-700 \mathrm{~kJ} / \mathrm{l}$ & $3-400 \mathrm{~kJ} / \mathrm{kg}$ & $150-200 \mathrm{~W} / \mathrm{kg}$ & nagy & $\begin{array}{c}2-4000 \\
\text { ciklus }\end{array}$ & $\begin{array}{c}\text { havonta } \\
3-4 \%\end{array}$ \\
\hline \multirow{2}{*}{ 岂 } & $\begin{array}{l}\text { porózus } \\
\text { grafén }\end{array}$ & $5-700$ kJ/l & $30-40 \mathrm{~kJ} / \mathrm{kg}$ & $10-15$ kW/kg & \multirow[t]{2}{*}{ minimális } & \multirow{2}{*}{$\begin{array}{l}10^{5}-10^{6} \\
\text { ciklus }^{8}\end{array}$} & \multirow{2}{*}{$\begin{array}{l}\text { óránként } \\
5-25 \%\end{array}$} \\
\hline & grafitoxid $^{9}$ & $800-1000 \mathrm{~kJ} / \mathrm{l}$ & $40-50 \mathrm{~kJ} / \mathrm{kg}$ & $15-20 \mathrm{~kW} / \mathrm{kg}$ & & & \\
\hline
\end{tabular}




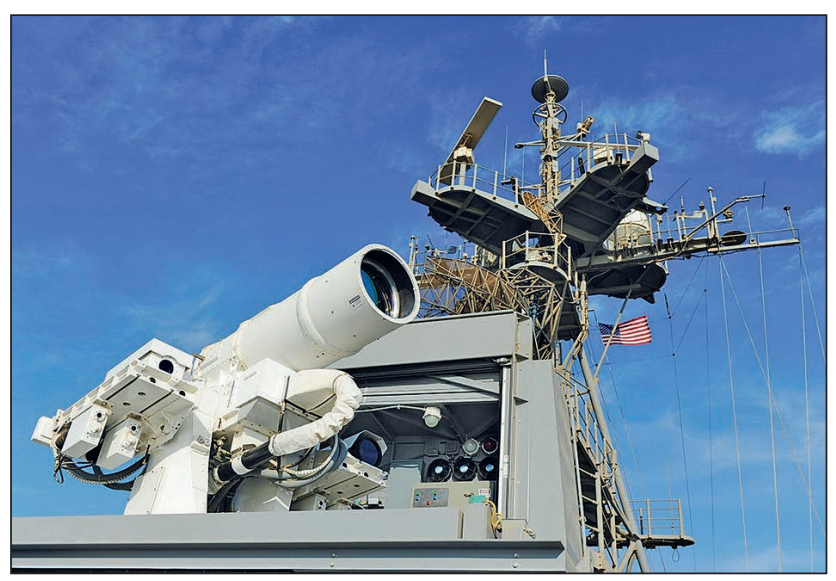

4. ábra. A San Antonio osztályba tartozó USS PORTLAND-ot már biztosan felszerelik a képen látható vízfelszíni rakéták ellen kifejlesztett lézerrel [10]

lenséges repülőgépeket, ballisztikus rakétákat, illetve hajó elleni rakétákat lézersugárral semmisítenek meg [9, 4549. o.]. Az a jelenség könnyen érthető, hogy a szükséges energiát a repülőgép turbinájával vagy a hajó motorjával megforgatott generátor képes előálítani, de hogyan kerül az energia a fegyverbe? Egy nagy távolságban gyorsan mozgó céltárgy esetében (ilyen a repülőgép is, valamint a rakéta) nincs lehetőség a célon tartani a lézernyalábot, egyetlen néhány milliszekundumos besugárzásban kell azt az energiát rávinni, ami képes megsemmisíteni. Egy ilyen ún. „átégető” típusú lézer, ami nemcsak a céltárgy navigációját zavarja, hanem ténylegesen megsemmisíti azt, kb. 10-100 kW impulzus-teljesítményt feltételez. Ekkora villamos energia néhány másodperces összegyűjtésére és néhány milliszekundumos leadására jelenleg csak a szuperkondenzátorok képesek.

\section{ELEKTROMÁGNESESEN GYORSítOTT LÖVEDÉKEK, AZAZ A RAILGUN}

A lézerhez hasonló a helyzet a railgun-nal. A fegyver érdekessége, hogy amíg a lézer csak repülőeszközök ellen hatékony (a repülőgépek többsége és a rakéták nincsenek páncélozva és egy nagy sebességgel mozgó tárgyat viszonylag kis sérülés is „röpképtelenné” tehet), addig a railgun bunkerek és harckocsik ellen is hatékony. A többszörös hangsebességgel becsapódó 12,7kg-os lövedék mozgási energiája több kg TNT-nek felel meg [11].

5. ábra. A railgun egyik első kísérleti lövése (Bae Systems)

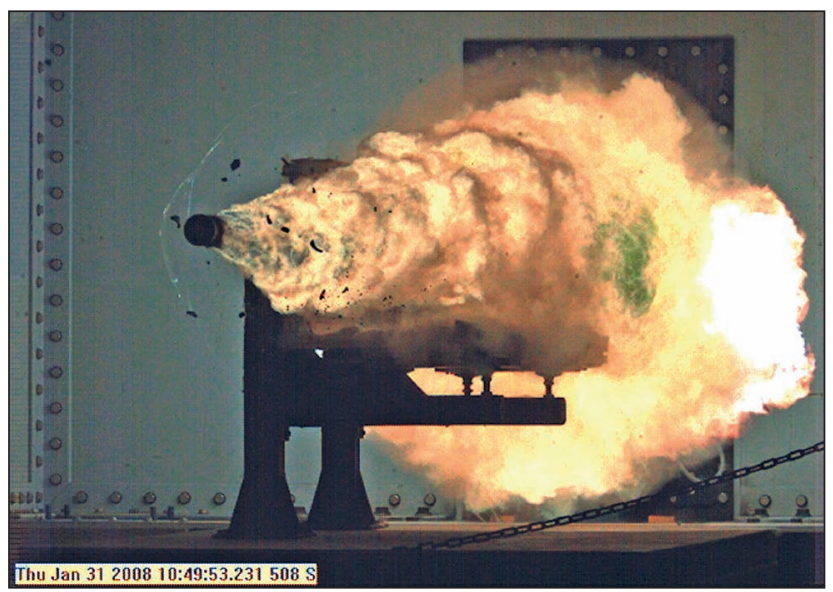

A railgun rendszeresítését az utolsó pillanatban - vélhetően anyagi megfontolások után - elhalasztották, de a fegyver már jelen állapotában is bevethető és összemérhető a hasonló rendeltetésű hagyományos hajóágyúkkal. „Az eddig publikált eredmények szerint a kész railgun elméletben percenként 10 HVP típusú lövedéket képes indítani, mintegy 7,5-szeres hangsebességgel (7,5 Mach). Ez közel 40 MJ-nyi torkolati energiát jelent, amihez a veszteségeket nem is számolva, legalább egy $200 \mathrm{MW}$-nyi villamos teljesítmény leadására képes kondenzátor szükséges. A tervezett tűzgyorsaságot figyelembe véve egy feltöltésre kb. 5-6 másodperc jut, az ehhez szükséges 40-50 MW villamos energiaigény mindenképpen jelentős terhet ró a hordozó platform villamos rendszerére. Összehasonlításképpen megemlíthetjük, hogy ha egy átlagos háztartás összes villamos gépét egyszerre kapcsoljuk be, az 3-6 kW terhelést ró a hálózatra, tehát nem túlzás azt álítani, hogy a railgun energiaigénye vetekszik egy kisebb városéval" [12].

\section{REPÜLÖGÉP-HORDOZÓ HAJÓK KATAPULTJA}

Azon kevés ország szakértői, amelyek rendszerben tartanak repülőgép-hordozókat, már régóta várják az elektromágneses katapultot, ugyanis a jelenleg alkalmazott gőzkatapultoknak számos gyenge pontja van. A gőzkatapult rendkívül nagy méretű, nehéz és bonyolult szerkezet. Mivel a tengervíz rendkívül agresszív korrodáló anyag, a szükséges gőzt sótalanított vízből fejlesztik, a sótalanítás pedig igencsak energiaigényes. A rendszer a turbinákból nyeri a gőzt, ezért nem kell külön kazánt fűteni, de a készenlét miatt a rendszert állandóan nyomáson kell tartani, illetve két start között is elég hosszú idő telik el a megfelelő gőznyomás újbóli eléréséhez. Az eltérő tömegű repülőgépekhez szükséges energia csak durván szabályozható, és az óriási rántás nagy igénybevételt jelent a gépek szerkezete számára. Mindezen túl a nagynyomású forró gőz fokozottan balesetveszélyes és a rendszernek nagy a karbantartás-igénye is [13].

Az Egyesült Államok legújabb szuperhordozója, a most próbaútját teljesítő USS GERARD FORD-on (CVN-78) a gőzkatapult helyett már elektromágneses indító egységek vagy rendszerek (EMALU vagy EMALS ${ }^{10}$ ) teljesítnek szolgálatot. Bár még tökéletesítésre szorulnak, elvben a gőzkatapult minden fent említett hibájától mentesek. Történetesen itt az indításhoz szükséges energiát még kinetikusan, óriási forgó rotorokban tárolják, de nyilvánvaló, hogy a jövő fejlesztése a hely- és karbantartás-igényes mechanikus elemek kiváltása [14, 331. o.].

\section{6. ábra. A USS GERARD FORD hordozó az EMALS-szel} (General Atomics)

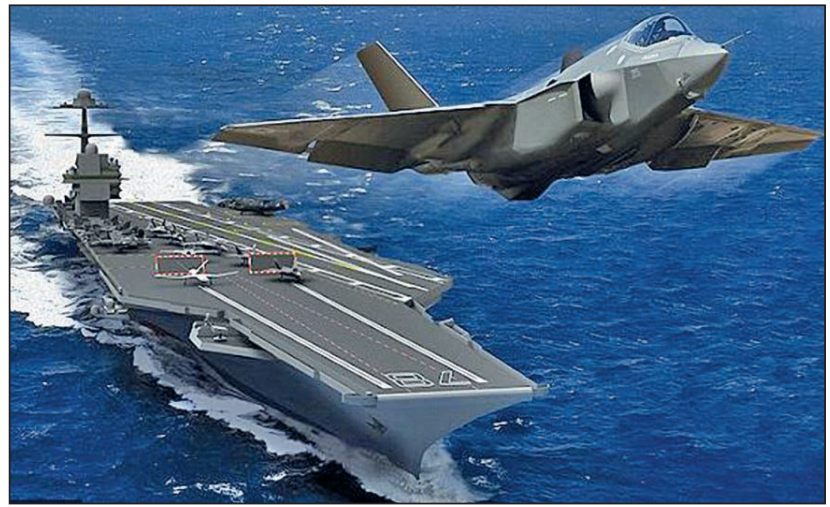




\section{GÉPJÁRMŰ HAJTÁSLÁNC}

Egyre többen foglalkoznak hibrid, illetve tisztán elektromos hajtásláncú gépjárművekkel. A jelenlegi technológiai szinten az ezekben a járművekben szükséges energia tárolására még csupán az akkumulátorok alkalmasak, de a szuperkondenzátorok képesek javítani a rendszer számos paraméterén. Ahogy azt korábban tárgyaltuk, az akkumulátorok vesztesége nagyobb terhelésnél jelentősen megnő, így elvben egy pufferként működő szuperkondenzátor jótékony hatással lehet a rendszer hatásfokára [15].

Mivel az akkumulátoroknak nagy hidegben nem csak az energiasűrüsége, hanem a teljesítménysűrüsége is romlik, egy puffer szuperkondenzátor segíthet a hagyományos dízelmotorok hidegindításakor szükséges nagy indítóáram biztosításában is. A kimondottan ilyen céllal gyártott ún. hibrid akkumulátorok már jelenleg is elérhetők [16].

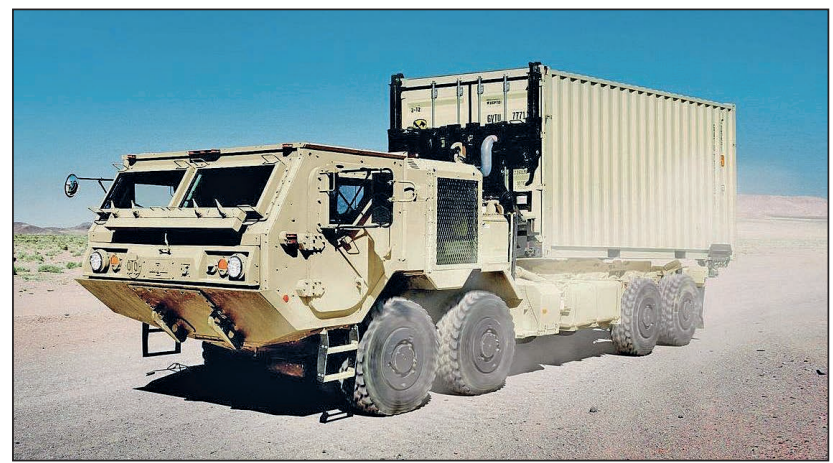

7. ábra. A jól bevált Oshkosh HEMTT már villamos hajtással is elérhető (TruckTrend)

A katonai járműveiről jól ismert amerikai Oshkosh még ennél is tovább lépett. A cég 2011-től felvette a kínálatába a már 35 éve gyártott HEMTT ${ }^{11}$ nehéz teherjármű legújabb - elektromos hajtású változatát is. Az A3 verzióban egy 470 LE-s Cummins dízelmotor található, amely nem a kerekeket, hanem egy $340 \mathrm{~kW}$-os generátort hajt. Ez folyamatosan tölt egy 1,9 MJ névleges kapacitású szuperkondenzátor-csoportot és egy inverteren keresztül erről hajtják a tengelyenként elhelyezett $4 \mathrm{db} 480 \mathrm{~V}$-os váltóáramú motort [17]. A ProPulse-nak nevezett megoldás a cég állítása szerint 20\%-kal kevesebb üzemanyagot fogyaszt, mint a hasonló teljesítményű egyszerű dízel változat, ám a rendszernek mégsem ez a legfontosabb újdonsága. A szuperkon-

8. ábra. A HEMTT ProPulse felépítése.

A - generátor, B - dízelmotor, C - szuperkondenzátorok, D - AC motorok (TruckTrend)

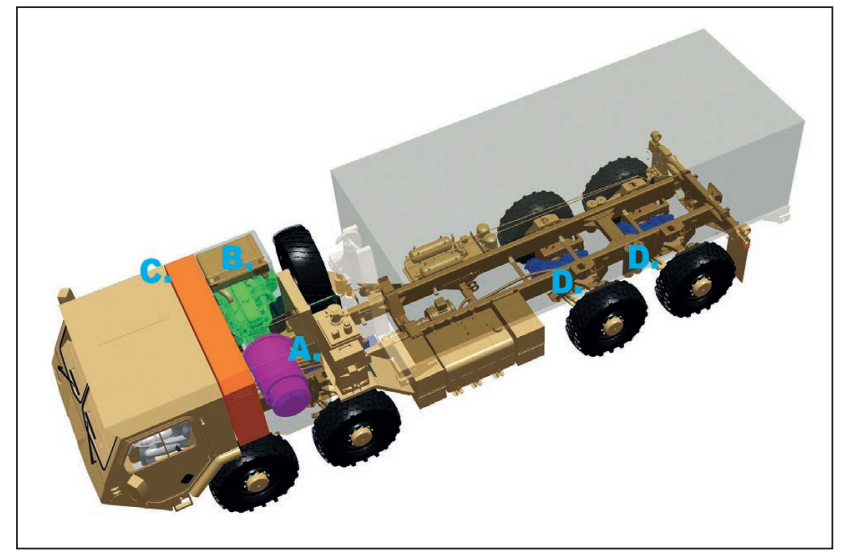

denzátoron keresztül a ProPulse alkalmas közepes fogyasztású katonai objektumok, kommunikációs állomások, tábori kórházak stb. tartós kiszolgálására, de a szuperkondenzátor akár 120 kW villamos teljesítmény-impulzus leadására is képes, így ideális platformja lehet lokátoroknak, szárazföldi telepítésű lézer, vagy railgun fegyver-rendszereknek is.

\section{KöVETKEZTETÉS}

Napjainkra már nem minden esetben a haditechnikai kutatás-fejlesztés képezi az innováció élvonalát. Gondoljunk csak az okoseszközökre, loT-re (Internet of Things) vagy épp az elektromobilitásra. A villamos energia iránti növekvő igény és a mobilitás utáni vágy a társadalom részéről sokkal erőteljesebb, mint a hadseregek igénye. Ennek eredményeként jelenleg a világ egyik legintenzívebben kutatott területe a villamos energia tárolása. Mindenki olyan tárolót szeretne, amelynek óriási a kapacitása, nagyon nagy teljesítmény leadására képes és jól bírja a hideget is. Most még nem látszik, hogy vajon egyszer majd lesznek-e olyan akkumulátorok, amelyek képesek a szuperkondenzátorokéhoz hasonló áramerősség leadására, vagy lesznek-e olyan szuperkondenzátorok, amelyek a mostaninál sokkal nagyobb kapacitásúak és hónapokig megőrzik a töltésüket. Esetleg elterjednek a hibrid akkumulátorok. Annyi bizonyos, hogy a szuperkondenzátorok már itt vannak, és egyes speciális katonai igények kielégítésére más technológia jelenleg nem is alkalmas. Mindemellett az is valószínűsíthető, hogy a jövőben csak nőni fog az alkalmazásuk gyakorisága a hadseregek eszközeiben.

\section{FELHASZNÁLt IRODALOM}

[1] Young, Grace. Leyden jar", Encyclopedia Britannica (online), 16-máj-2013, https://www.britannica.com/ technology/Leyden-jar. (Letöltés 2018. jan. 19);

[2] Gergely István. Elektrotechnika. Budapest: General Press, 2006.;

[3] Dubilier, William. „Electric Condenser”, US Patent no. 468787.;

[4] Katsuhiko, Naoi és Simon, Patrice. „New Materials and New Configurations for Advanced Electrochemical Capacitors", Electrochem. Soc. Interface, 17, évf. 2008/1, 34-37, o.;

[5] Zhong, Cheng. Electrolytes for electrochemical supercapacitors. Boca Raton: CRC Press, 2016. https://doi.org/10.1201/b21497;

[6] Guerra, Maria. „Can Supercapacitors Surpass Batteries for Energy Storage?" Electronic Design, http://www.electronicdesign.com/power/cansupercapacitors-surpass-batteries-energy-storage (Letöltés: 2018.01.22);

[7] Végvári Zsolt. „Akkumulátorok a gyalogos lövészkatonák felszerelésében, a fejlesztés lehetséges irányai”, Müszaki Katonai Közlöny, 26. évf. 2016/2, 85-101. 0.;

[8] Yu, Aiping, Chabot, Victor és Zhang, Jiujun. Electrochemical supercapacitors for energy storage and delivery: fundamentals and applications. Boca Raton, FL: CRC Press, 2013. https://doi.org/10.1201/b14671;

[9] Ványa László. Irányított energiájú fegyverek. Budapest: Nemzeti Közszolgálati Egyetem, 2013;

[10] Insinna, Valerie. US Navy's next amphibious warship to get laser weapon", Defense News (online), 
11-2018, https://www.defensenews.com/digitalshow-dailies/surface-navy-association/2018/01/10/ navys-next-amphibious-warship-to-get-laserweapon/. (Letöltés: 2018.01.20);

[11] Végvári Zsolt. „Elektromágnesesen gyorsított lövedékek a tüzérség eszköztárában, A Bae Systems EM railgun-ja 1. rész", Haditechnika, 51. évf. 2017/1, 28-31. o. DOI: 10.23713/HT.51.1.06;

[12] Végvári Zsolt. „Elektromágnesesen gyorsított lövedékek a tüzérség eszköztárában, A Bae Systems EM railgun-ja 2. rész", Haditechnika, 51. évf. 2017/2, 18-22. o. https://doi.org/10.23713/HT.51.2.04;

[13] Allamadani, Ramh és Chen, Feng. „Electromagnetic Aircraft Launching Unit (EMALU)", előadás, ASEE 2014 Zone, Bridgeport, 2014;

[14] Yu, Aiping, Chabot, Victor és Zhang, Jiujun. Electrochemical supercapacitors for energy storage and delivery: fundamentals and applications. Boca
Raton: Taylor \& Francis, 2013. https://doi. org/10.1201/b14671;

[15] Mihalczuk, Marek, Grzesiak, Lech M., és Ufnalski, Bartlomiej. „A lithium battery and ultracapacitor hybrid energy source for an urban electric vehicle", Przeglad Eelektrotekniczny, 88. évf. 2012/4, 158-162. o. http://ufnalski.edu.pl/zne/papers/29 PE_04b_12_158-162_michalczuk.pdf Letöltve: 2018.09.26.;

[16] „Maxwell Technologies Engine Starting Module”, Maxwell Technologies. (online). http://www.maxwell. com/esm/default.aspx. [Letöltés: 2018.01.22.];

[17] Thompson, Jason. „The Diesel-Electric Hybrid HEMTT A3 Lean by OSHKOSH - Diesel Power Magazine", Truck Trend, (online), 01-júl-2011, http:// www.trucktrend.com/cool-trucks/1107dp-dieselelectric-hybrid-hemtt-oskosh-a3/, Letöltve: 2017.11.28.

\section{JeGYZETEK}

1 A két fegyverzetet és az azokat elválasztó papír dielektrikumot a kisebb méret miatt felcsévélték.

2 A jelenség váltakozó feszültséggel is működik, de ebben az esetben egy differenciálegyenlet írja azt le, amelyet e cikk keretében nem tárgyalunk.

A továbbiakban kizárólag az energiatárolás szempontjából releváns egyenfeszültségű alkalmazásokkal foglalkozunk.

3 A kapacitás angol neve a "capacity”, amelyről az eszköz angol neve, a „capacitor” is származik.

$4 \mathrm{Az}$ angol irodalomban a szuperkondenzátornak megfelelő „supercapacitor” kifejezésen kívül még használatos az „ultracapacitor”, illetve „supercap" és "goldcap" is.

5 Electric Double Layer Capacitor.

6 Elektrokémiai tárolóeszköz a szárazelem is, de mivel itt mindössze egy ciklusról beszélhetünk, ez a technológia nem tekinthető a szuperkondenzátorok közvetlen riválisának.

7 Equivalent Serial Resistance.

8 Mivel az egymillió már egy ciklus, így nehezen értelmezhető, illetve a ciklusok gyorsasága miatt a használatuk lényegében folyamatos, a szuperkondenzátorok élettartamát a gyakorlatban inkább órában szokták megadni, ami legkevesebb 10000 óra körüli.

9 A megnevezésnél egyszerűsített, a technológia teljes angol neve: activated microwave exfoliated graphite oxide (a-MEGO)/1-ethyl-3-

methylimidazolium bis(trifluoromethylsulfonyl)imide.

10 Electromagnetic Launch Unit/System.

11 Heavy Expanded Mobility Tactical Truck - Kiterjesztett mobilitású nehéz taktikai tehergépjármü.

\section{HM ZRÍNYI TÉRKÉPÉSZETI ÉS KOMMUNIKÁCIÓS SZOLGÁLTATÓ KÖZHASZNÚ NKFT.}

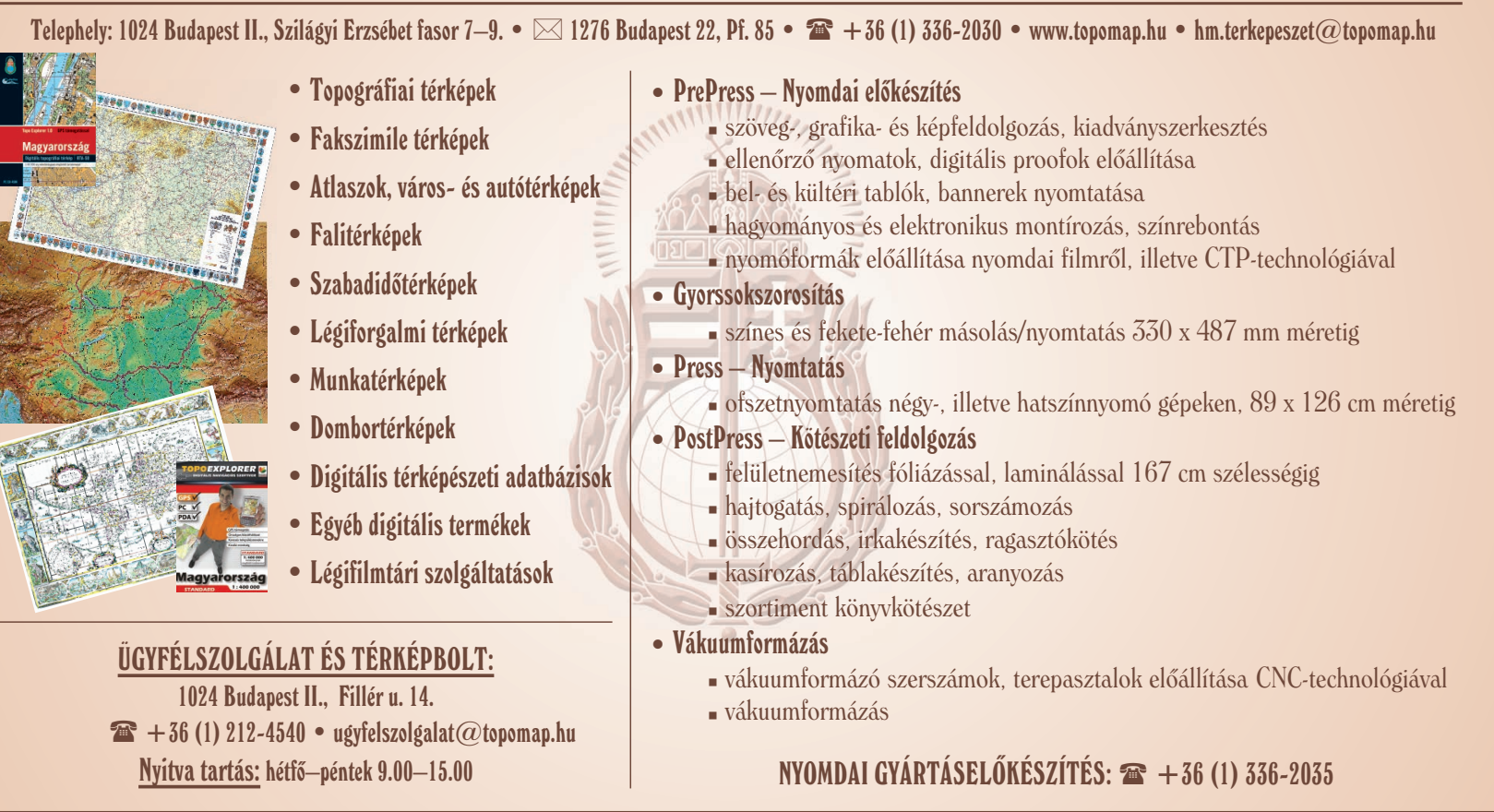

